\title{
Quantification of antibiotic resistance genes and mobile genetic in dairy manure
}

\author{
Yi Wang ${ }^{1}$, Pramod Pandey ${ }^{\text {Corresp., } 1}$, Colleen Chiu ${ }^{1}$, Richard Jeannotte ${ }^{1,2}$, Sundaram Kuppu ${ }^{1}$, Ruihong Zhang ${ }^{3}$, \\ Richard Pereira ${ }^{1}$, Bart C Weimer ${ }^{1}$, Nitin Nitin ${ }^{4}$, Sharif S Aly ${ }^{1,5}$ \\ ${ }^{1}$ Department of Population Health and Reproduction, University of California, Davis, Davis, California, United States \\ Department of Plant Science, University of California, Davis, Davis, California, United States \\ 3 Department of Biological and Agricultural Engineering, University of California, Davis, Davis, California, United States \\ 4 Department of Food Science and Technology, University of California, Davis, Davis, California, United States \\ 5 Veterinary Medicine Teaching and Research Center, School of Veterinary Medicine, University of California, Davis, Davis, California, United States \\ Corresponding Author: Pramod Pandey \\ Email address: pkpandey@ucdavis.edu
}

Background. Antibiotic resistance genes (ARGs) are considered to be emerging environmental contaminants of concern potentially posing risks to human and animal health, and this research studied the prevalence of antimicrobial resistance in dairy manure.

Methods. This study is focused on investigating prevalence of ARGs in California dairy farm manure under current common different manure management. A total of 33 manure samples were collected from multiple manure treatment conditions: 1 ) flushed manure (FM), 2) fresh pile (FP), 3) compost pile (CP), 4) primary lagoon (PL), and 5) secondary lagoon (SL). After DNA extraction, all fecal samples were screened by PCR for the presence of 8 ARGs: four sulfonamide ARGs (sull, sullI, sullI, sulA), two tetracycline ARGs (tetW, tetO), two macrolide-lincosamide-streptogramin B ( $\mathrm{MLS}_{\mathrm{B}}$ ) ARGs (ermB, ermF). Samples were also screened for two mobile genetic elements (MGEs) (intl1, tnpA), which are responsible for dissemination of ARGs. Quantitative PCR was then used to screen all samples for five ARGs (sullI, tetW, ermF, tnpA and intl1).

Results. Prevalence of genes varied among sample types, but all genes were detectable in different manure types. Results showed that liquid-solid separation, piling, and lagoon conditions had limited effects on reducing ARGs and MGEs, and the effect was only found significant on tetW $(p=0.01)$. Besides, network analysis indicated that sulll was associated with tnpA $(p<0.05)$, and Psychrobacter and Pseudomonas as opportunistic human pathogens, were potential ARG/MGE hosts $(p<0.05)$. This research indicated current different manure management practices in California dairy farms has limited effects on reducing ARGs and MGEs. Improvement of different manure management in dairy farms is thus important to mitigate dissemination of ARGs into the environment. 
1 Quantification of antibiotic resistance genes and mobile genetic in dairy manure

2 Yi Wang ${ }^{1,2}$, Pramod Pandey ${ }^{1}$, Colleen Chiu ${ }^{1}$, Richard Jeannotte ${ }^{3}$, Sundaram Kuppu ${ }^{1}$, Ruihong

3 Zhang $^{2}$, Richard Pereira ${ }^{1}$, Bart Weimer ${ }^{1}$, Nitin Nitin ${ }^{4}$, Sharif S. Aly ${ }^{1,5}$

4

$5 \quad{ }^{1}$ Department of Population Health and Reproduction, School of Veterinary Medicine, University

6 of California-Davis, Davis, California, USA

$7 \quad{ }^{2}$ Department of Biological and Agricultural Engineering, University of California-Davis, Davis,

8 California, USA

$9 \quad$ Department of Plant Science, University of California Davis, , Davis, California, USA

$10{ }^{4}$ Department of Food Science and Technology, University of California-Davis, Davis, California, 11 USA

$12{ }^{5}$ Veterinary Medicine Teaching and Research Center, School of Veterinary Medicine, University 13 of California, Davis, California, USA

14

15

16

17

18

19

20

21

22

23

24

25

26

27

Corresponding Author:

Pramod Pandey

University of California-Davis, Davis, California, USA

Email address: pkpandey@ucdavis.edu

\section{Abstract}

Background. Antibiotic resistance genes (ARGs) are considered to be emerging environmental contaminants of concern, which poses risks to human and animal health, and this research studied the prevalence of antimicrobial resistance in dairy manure under various manure management practices.

Methods. This study is focused on investigating the prevalence of ARGs in California dairy farm manure under different manure management practices. A total of 33 manure samples were 
28 collected from various farms under multiple manure treatment conditions: 1) flushed manure

29 (FM), 2) fresh pile (FP), 3) compost pile (CP), 4) primary lagoon (PL), and 5) secondary lagoon

30 (SL). Manure samples of these treatments were collected for DNA extraction. After DNA

31 extraction, DNAs of all fecal samples were screened by PCR for the presence of 8 ARGs: four

32 sulfonamide ARGs (sulI, sulII, sulIII, sulA), two tetracycline ARGs (tet $W$, tetO), two macrolide-

33 lincosamide-streptogramin B $\left(\mathrm{MLS}_{\mathrm{B}}\right)$ ARGs (ermB, ermF). DNAs samples were also screened

34 for two mobile genetic elements (MGEs) (intI1, tnpA), which are considered to be responsible

35 for the dissemination of ARGs in the environment. In addition to PCR, Quantitative PCR (qPCR)

36 was used to screen DNA samples for five ARGs (sulII, tet $W$, ermF, tnpA and intIl).

37 Results. Results of PCR and qPCR showed the prevalence of various genes in dairy manure

38 samples. All tested genes were detectable in different types of manure samples. Liquid-solid

39 separation, piling, and lagoon conditions had limited effects on reducing ARGs and MGEs, and

40 the effect of these treatments was significant in $\operatorname{tet} W(p=0.01)$ reductions. This research

41 indicated current different manure management practices in California dairy farms have limited

42 effects on reducing ARGs and MGEs. Improvement in different manure management practices

43 in dairy farms is thus important to investigate for mitigating the dissemination of ARGs into the

44 environment.

\section{Introduction}

46 Antibiotic resistance is an emerging concern to public health (CDC 2013; Frieri et al. 2017;

47 Pang et al. 2019; Zaman et al. 2017). In the United States of America, it is estimated that more

48 than 2.8 million people are possibly infected by antibiotic-resistant bacteria each year (CDC

49 2019). The total economic cost to the U.S. economy is estimated up to $\$ 55$ billion a year due to

50 lost wages, extended hospital stays, and premature deaths (CDC 2013; Roberts et al. 2009). The

51 use of antibiotics in animal husbandry is one of the leading factors causing widespread antibiotic - - 
52 resistance (CDC 2019). Every year, approximately $80 \%$ of all antimicrobial drugs are applied in

53 animal farming to treat/prevent infectious diseases (FDA 2012; FDA 2013). Out of this,

54 approximately $70 \%$ is used for non-therapeutic purposes (UCS 2001). The elevated quantity of

55 antibiotic residue in fecal matter is potentially due to low absorption in the cattle body (Jjemba 56 2002).

57 Dairy manure is used as fertilizers in cropland, and potential impacts of manure borne 58 antibiotic resistance genes (ARGs) on the environment are yet to be fully understood (Baquero et 59 al. 2008; Han et al. 2018; Kumar et al. 2005; Wind et al. 2018; Zhao et al. 2017). Dairy manure 60 is considered potential mediator and reservoir for ARGs (Allen et al. 2010; Guardabassi et al. 61 2004). When dairy manures are applied as fertilizer, manure born ARGs and antibiotic residues 62 may transfer into crop land soil, and subsequently to ambient water bodies (Bennett 2008; 63 Gogarten and Townsend 2005).

64 Previous research showed that antibiotic resistance in environmental bacteria is selected 65 by antibiotic residues (Baquero et al. 2008; Pruden et al. 2013), and ARGs can proliferate in the 66 host bacteria and transfer to other microbes, including human pathogens, through horizontal gene 67 transfers (HGTs) (Bennett 2008; Gogarten and Townsend 2005).

68 In terms of quantity, more than 369 million tons of manure are produced in the USA 69 annually (USDA 2012), and the majority of this dairy manure is used as fertilizer in various 70 cropland. Currently, California is the top milk producing state in the United States of America, 71 and dairy farms also produces around 60 million tons of manure annually (USDA 2016).

72 While managing manure in dairy farms, the flushed system is one of the most commonly

73 adopted methods for manure handling and management in dairy farms in California. Flush 74 system has many benefits, including low labor, ease of handling, and reduced operating cost 
75 (CARB 2017; Kaffka et al. 2016; Meyer et al. 2011), however, it also produces enormous 76 amount of liquid manure. Identifying the suitable treatment methods, which can reduce the

77 contamination levels in manure is important for food safety. Therefore, this study was focused on

78 studying the prevalence of ARGs in the flush manure management system. In a flushed system

79 (Fig. 1), a dairy barn is flushed with recycled water from a lagoon system which holds liquid

80 manure and then flushed manure passes through a liquid-solid separator, where it is separated

81 into solid and liquid waste streams. Solid manure is piled, and in some cases, it is composted in

82 dairy farms before being applied into cropland as fertilizers.

83 Previous reports emphasize the importance of understanding the fate of ARGs in

84 livestock manure treatments (Flores-Orozco et al. 2020; Gou et al. 2018; Howes 2017; Ma et al.

85 2018). The abundance of ARGs in livestock waste varies among farm types and locations (He et

86 al. 2020). McKinney et al. (2010) examined the behavior of ARGs in eight livestock lagoon

87 systems. Hurst et al. (2019) studied the abundance of 13 ARGs in untreated manure blend pits.

88 The authors found ARGs abundance varied among farms, and ARG concentrations generally did

89 not correlate to average antimicrobial usage due to complex environmental factors (Flores-

90 Orozco et al. 2020; Huang et al. 2019; Pei et al. 2007; Selvam et al. 2012; Sun et al. 2016; Wang

91 et al. 2012).

92 Previous findings of an investigation in three pig farm wastewater treatment systems in

93 China showed a relative abundance, and most ARGs were significantly higher in wastewater

94 lagoon than in fresh manures even after treatment (Cheng et al. 2013). Though these studies do

95 provide preliminary understanding, knowledge about the ARGs in California flushed system in

96 dairy farm is yet to be understood. 
While issues of antibiotics in environment are considered important, standard guidelines

98

99

100

101

102

103

104

105

106

107

108

109

110

111

112

113

114

115

119

117 Solid and liquid manure sampling in dairy farms

118 In dairy farms, liquid and solid dairy manure samples were collected in California Central Valley

and practices capable of reducing antibiotic resistance are yet to be proposed (Allen et al. 2010

D'Costa et al. 2006; Ghosh and LaPara 2007). Currently, knowledge of species and antibiotic resistance profile of unculturable bacteria is lacking. The use of culture-independent methods, such as polymerase chain reaction (PCR) and quantitative polymerase chain reaction (qPCR) are preferred due to simplicity and fast results and have the potential to produce relatively more comprehensive and reproducible knowledge of ARG profiles.

Considering the importance of animal-agricultural system in food supply, and associated by products, understanding the role of various manure management practices in reducing manure borne contamination is crucial for both public health and environmental health. Human health is closely connected to animal health and their shared environment (One Health), therefore, it is important to explore antimicrobial resistance genes content of manure and the optimal management practices to reduce ARGs content for reducing unwanted potential impacts on reduced efficacy of antimicrobial drugs in clinical practice. The aim of this study was to investigate the fate of ARGs and MGEs in manure under the flushed manure management system. The specific objectives of this research were: 1) estimate the prevalence of antibiotic resistance genes in manure under different manure management practices; 2) quantify ARGs and MGEs in dairy manure; and 3) determine the relationships among ARGs, MGEs, and microbial communities.

\section{Materials \& Methods} from multiple dairy farms (Pandey et al. 2018). Thirty-three solid/liquid manure samples were 
120 collected from Tulare, Glenn, and Merced counties in California Central Valley. California

121 Central Valley has approximately 91 percent of dairy cows and over 80 percent of dairy facilities

122 in California (CARB 2017). In dairy farms, solid manure samples were collected from fresh/old

123 piles ( 0 to 6 months old) $(n=14)$, and liquid manure samples were collected from flushed

124 manure pits and primary/secondary lagoons ( 0 to 6 months old storage $)(n=19)$. The solid

125 manure samples collected from fresh piles (less than 2 weeks old pile) were termed as Fresh Pile

126 (FP). The solid samples collected from old piles were termed as Compost Pile (CP). The studied

127 CP here does not necessarily mean that the piles were maintained under thermophilic

128 temperature and mixing conditions of a standard composting process. Similarly, lagoon system

129 in dairy farms were not necessarily under strict anaerobic environments. The liquid manure

130 samples collected from flushed manure pit were termed as Flushed Manure (FM), while the

131 liquid manure samples collected from primary lagoons and secondary lagoons were termed as

132 Primary Lagoon (PL) and Secondary Lagoon (SL), respectively. In each dairy facility, $1 \mathrm{~L}$ of

133 liquid manure sample from each pond, and approximately 500-600 $\mathrm{g}$ of solid manure from each

134 pile were collected in sterile bottles. Samples were then transported on wet ice after collection

135 and stored at $-20{ }^{\circ} \mathrm{C}$ before DNA extraction.

136 DNA extraction from manure samples

137 In manure samples, genomic DNA was extracted either using the MO BIO PowerSoil ${ }^{\circ}$ DNA

138 Isolation Kit or MO BIO PowerWater® DNA Isolation Kit (MO BIO Laboratories Inc.). All

139 solid samples and liquid samples with turbid and sludge-like consistency were processed by the

140 MO BIO PowerSoil $\AA$ kit. For sludge-like liquid samples (sample with high solid), $10 \mathrm{~mL}$ of

141 each sample were centrifuged in $50 \mathrm{~mL}$ polypropylene tubes at $13,000 \mathrm{rpm}$ for 10 minutes and

$1420.25 \mathrm{~g}$ of the resulting pellet was used for bead beating. Liquid samples with clear-to-low 
143 turbidity were processed by the MO BIO PowerWater ${ }^{\circledR}$ kit, and $10-200 \mathrm{~mL}$ of each was filtered

144 through a Millipore filter $(0.45-\mu \mathrm{m}$ pore size). The quality and concentration of the DNA were

145 assessed by NanoDrop 1000 spectrophotometer (Thermo Scientific). All extracted DNA from

146 manure samples were stored at $-20^{\circ} \mathrm{C}$ before PCR amplification.

147 PCR assays for detection of resistance genes in manure

148 PCR assays for detection of sul, tet and erm were designed. It was reported sul, tet and erm are

149 three of the most frequently detected ARGs classes in livestock waste, which match the major

150 classes of antibiotics used in animal growth promotion and disease control (He et al., 2020).

151 Primers designed in previous work targeting sul, tet and erm genes were used in this study to

152 amplify ARGs (Garder et al. 2014; Hu et al. 2015; Pei et al. 2007), which are shown in Table 1.

153 Subsequently, PCR assays were performed to determine gene detectability in the manure

154 samples. These assays were carried out using the KAPA2G Robust HotStart Ready Mix PCR Kit

155 (KAPA) in a $25 \mu \mathrm{L}$ volume reaction. The PCR reaction consisted $12.5 \mu \mathrm{L} 2 \mathrm{x}$ KAPA2G Robust

156 Hotstart Ready Mix, $1.25 \mu \mathrm{L} 10 \mathrm{mM}$ each primer, and $2 \mu \mathrm{L}$ of the template. The temperature

157 program consisted of initial denaturation at $95^{\circ} \mathrm{C}$, followed by 40 cycles of $15 \mathrm{~s}$ at $95^{\circ} \mathrm{C} ; 30 \mathrm{~s}$ at

158 the $60^{\circ} \mathrm{C}\left(55^{\circ} \mathrm{C}\right.$ for tet $O$, tet $W, e r m B$ and $\left.e r m F\right) ; 30 \mathrm{~s}$ at $72^{\circ} \mathrm{C}$, and a final extension step for 1

$159 \min$ at $72^{\circ} \mathrm{C}$. Primer and temperature conditions for intI and tnpA genes are presented in Table 1.

160 PCR products were verified by gel electrophoresis. Purificaiotn, and cloning was done using the

161 TOPO TA Cloning Kit (Invitrogen) according to the manufacturer's instructions. Subsequently,

162 clones were sequenced to verify the insert of the targeted gene (sequencing and verification

163 results are shown in Fig. S1-S6). Plasmids carrying the target genes were extracted and used as

164 positive controls for qPCR to generate standard curves.

165 Real-time quantitative PCR (RT-qPCR) analysis in manure 
166 Targeted genes and 16S rRNA gene qPCR reactions were performed using a StepOnePlus ${ }^{\mathrm{TM}}$

167 System (Life Technology) in a $20 \mu \mathrm{L}$ of reaction mixture (10 $\mu \mathrm{L}$ PowerUp ${ }^{\mathrm{TM}} \mathrm{SYBR}^{\mathrm{TM}}$ Green

168 Master Mix [2x]) (Life Technology), $2 \mu \mathrm{L}$ of $10 \mathrm{mM}$ each primer, and $2 \mu \mathrm{L}$ of template) with a 169 temperature program of 2 min at $50{ }^{\circ} \mathrm{C}$ for UDG activation and 2 min at $95{ }^{\circ} \mathrm{C}$ for Dual-Lock ${ }^{\mathrm{TM}}$ 170 DNA polymerase activation. This was followed by 40 cycles of $15 \mathrm{~s}$ at $95{ }^{\circ} \mathrm{C} ; 15 \mathrm{~s}$ at $50{ }^{\circ} \mathrm{C}-60$

$171{ }^{\circ} \mathrm{C}\left(60{ }^{\circ} \mathrm{C}\right.$ for $\mathrm{T}_{\mathrm{m}}>60{ }^{\circ} \mathrm{C}$ and at $\mathrm{T}_{\mathrm{m}}$ for $\left.\mathrm{T}_{\mathrm{m}}<60{ }^{\circ} \mathrm{C}\right) ; 1 \mathrm{~min}$ at $72{ }^{\circ} \mathrm{C}$. Each reaction was 172 conducted in triplicates.

173 The average copy and standard deviation were calculated using triplicate for each

174 reaction. Melting curve analysis was used to detect nonspecific amplification. Standard curves 175 were included in each qPCR plate by performing serial 10-fold dilutions of the standards. The 176 efficiency of the PCR was calculated by Efficiency $=10^{-(1 / \text { slope })}-1$. All standard curves had a $r^{2}$ $177>0.99$ and an amplification efficiency of $90 \%-110 \%$. The detection limit for each gene was 178 determined by the highest dilution that produced a consistent $\mathrm{C}_{\mathrm{T}}$ value (within $5 \%$ deviation). If 179 the standard deviation was more than 5\% then two samples with the smallest difference were 180 used for calculation.

181 The absolute copy number of genes was quantified by referring to the corresponding 182 standard curve obtained by plotting threshold cycles versus log-copy number of genes. Levels of 183 targeted genes were normalized as the percentage of copy number of a gene/copy number of $16 \mathrm{~S}$ 184 rRNA gene for each sample to emphasize the relative abundance in environmental samples 185 (Alexander et al. 2011; Marti et al. 2013; Selvam et al. 2012).

$18616 S$ rRNA gene sequencing in manure samples

187 The high-throughput sequencing for 16S rRNA gene is described elsewhere (Pandey et al. 2018).

188 Sequencing was performed by DNA Technologies Core Facility of the Genome Center at the 
189 University of California-Davis using the Illumina MiSeq platform. The V3 and V4 hypervariable 190 region of the $16 \mathrm{~S}$ rRNA gene was amplified using the forward primer: (5'-

191 TCGTCGGCAGCGTCAGATGTGTATAAGAGACAGCCTACGGGNGGCWGCAG-3') and 192 the reverse primer: $\left(5^{\prime}-\right.$

193 GTCTCGTGGGCTCGGAGATGTGTATAAGAGACAGGACTACHVGGGTATCTAATCC-

$1943^{\prime}$ ) (Klindworth et al. 2013). For quality control, barcodes and primers were allowed to have 1

195 and 4 mismatches, respectively. Primer sequence reads were then trimmed, and sequences were

196 merged into a single amplicon sequence using FLASH2. Assignment of sequence to phylotypes

197 was performed in the RDP database using the RDP Bayesian classifier (bootstrap confidence

198 score $>50 \%$ ). Further, covariates were generated using relative abundance of bacterial taxa in

199 each sample. Stepwise discriminant analysis models built in JMP Pro 13.0 were performed until

200 only variables with a $p$-value $<0.05$ were retained (Pandey et al., 2018).

201 Data analysis

202 Statistical analysis on gene abundance data was performed using the published approaches

203 (Burch et al. 2016; Sandberg and LaPara 2016; Sun et al. 2016). Data were log-transformed 204 before statistical analysis. Ordinary one-way ANOVA was used to evaluate the influence of 205 dairy manure conditions on gene reductions by GraphPad Prism 8. Residuals were checked by 206 Brown-Forsythe test of heteroscedasticity and Anderson-Darling test of normality $(\alpha=0.05)$.

207 Tukey's multiple comparison test was used for comparing gene levels under different conditions $208(\alpha=0.05)$. Multiplicity adjusted $p$-value was reported for each comparison. Principal Component 209 Analysis (PCA) Plot and Hierarchical Clustering Plot were conducted by MetaboAnalyst 3.0 to 210 find similarity among samples. Correlation networks were created by MetScape 3.1.3 and 211 Cytoscape 3.4.0. CorrelationCalculator 1.0.1 was used based on Debiased Sparse Partial 
212 Correlation (DSPC) method to calculate partial correlation values and $p$-values for each pair in

213 the network. Range for edges was set to partial correlation values (corr. pcor) of $<-0.20$ or $>$

$214+0.20$.

215 Results

216 PCR for gene presence

217 Firstly, PCR assays were applied to explore whether the gene was detectable or not in each 218 sample. PCR screening results in all 33 samples are shown in Table 2. Four different manure 219 management groups, FP, FM, PL, and SL, had similar positive percentages of gene types. CP 220 group had a significantly lower percentage $(p=0.02)$, with an average of $47 \%$ types of targeted 221 genes. One sample (PL2) was found with no detection. Four samples (FP1, FP5, FP7, and SL4)

222 were found with all ten genes. The most abundant gene was sulII, and it was present in a total of $22393.9 \%$ among all samples, with a percentage of $92.9 \%$ in solid samples and $94.7 \%$ in liquid 224 samples. The lowest one, sulA, was positive in a total of $12.1 \%$ among all samples, and was 225 detected in 21.4\% solid samples and 5.3\% liquid samples. Liquid samples normally had a higher 226 percentage of detectable genes, except for sulIII and sul $A$. sulII, tet $W$, ermF, tnpA and intII were 227 selected for further study to quantify the gene concentrations because of their representation of 228 different antibiotic resistance mechanisms and high prevalence among the samples. Fisher's 229 exact test for contingency table analysis showed the overall gene detection rate in CP group was 230 significantly lower than FP, FM, PL, and SL $(p<0.01)$.

231 Quantification of resistance related genes

232 Five genes (sulII, tet $W, e r m F, \operatorname{tnp} A$ and $i n t I I)$ were quantified by qPCR in 33 dairy manure 233 samples taken from different manure management conditions. DNA templates for qPCR were 234 the same batch of extractions as PCR (Table 1). The numbers of copies of the five resistance 
235 related genes quantified at each sample were then normalized to the number of copies of 236 bacterial 16S rRNA gene. Data is shown in Table S1. As shown in Fig. 2 (Table S1), the average gene concentrations for sulII, tetW, and intII

238

239 were similar $\left(\sim 1 \times 10^{-4}\right.$ gene copies $/ 16 \mathrm{~S}$ rDNA copies $)$. The tet $W$ was the highest $\left(1.43 \times 10^{-4}\right.$ gene copies/16S rDNA copies). The concentrations of $e r m F$ and tnp $A$ were $5.98 \times 10^{-6}$ and 4.67 $\times 10^{-5}$ (gene copies/16S rDNA copies), respectively (lower by one and two order of magnitudes). In ordinary one-way ANOVA, diagnostic of residuals showed data passed BrownForsythe test and Anderson-Darling test $(\alpha=0.05)$. One-way ANOVA showed different manure management had no significant effect on four of the five genes. Effect of different manure management practices was only found significant on $\operatorname{tet} W(p=0.01)$. Tukey test for multiple comparisons showed tet $W$ in Compost Pile were significantly lower than Flushed Manure (adjusted $p=0.02$ ) and Primary Lagoon (adjusted $p=0.02$ ).

PCA and cluster plots for relative abundance of five genes were drawn by MetaboAnalyst 3.0 (Xia et al. 2015) as shown in Fig. 3. Relative abundance of five genes were log transformed and then normalized by median, followed by mean centering as the data scaling method. Figure 3 (a) shows PC 1 captured $40.1 \%$ of the variation between samples, and PC 2 captured $23.4 \%$. These two PCs captured $63.5 \%$ of the variation between the samples. The CP, FP, PL, SL, and FM groups were overlapped, which means they were not significantly different from each other. In agglomerative hierarchical cluster analysis shown in Fig. 3 (b), each sample began as a separate cluster and the algorithm proceeded to combine them until all samples belonged to one cluster. Results showed that PL and FM, CP and FP were similar, as they tended to cluster together. However, different manure conditions did not fall into separate clusters, indicating their ARG profiles were not significantly different from each other. As the CP, FP, PL, SL, and FM 
258 groups were overlapped in Fig. 3 (a) and did not fall into separate clusters in Fig. 3 (b), it can be

259 inferred that liquid-solid separation, lagoon system and piling process may have limited to no

260 impacts on ARGs reductions.

261 Cooccurrence of ARGs, MGEs, and microbial communities

262 Figure 4 shows the correlation network of five genes with top 50 bacterial taxa in the manure

263 samples. Bacterial community data was used for network analysis. Range for edges was set to

264 partial correlation values (corr. pcor) of $<-0.20$ or $>+0.20$. Red lines indicate positive

265 correlation, while blue lines represent negative correlation. A bold line shows a $p$-value less than

266 0.05. These were three significant correlations: tnpA-sulII (corr. pcor $=0.415)$; intII -

267 Psychrobacter (corr. pcor $=0.519)$; ermF - Pseudomonas $($ corr. pcor $=0.466)$.

268

269 Discussion

270 Prevalence and quantification of resistance related genes

271 The PCR results showed manure under different conditions possessed variety of ARGs and

272 MGEs. Both traditional PCR and RT-qPCR were able to amplify DNA. RT-qPCR provided both

273 qualitative and quantitative data by measuring the kinetics of the reaction in the exponential

274 phase. Traditional method by agarose gels provided only qualitative results by measuring

275 amplification products at endpoint of the PCR reaction (Parashar et al. 2006). In our study,

276 targeted genes were screened firstly by PCR and selected gene were then quantified by RT-

277 qPCR. It was noticed that some of genes were not detectable in PCR, and the same genes were

278 detectable in qPCR. For example, sulII, tnpA and intI1 in PL2 were detectable in qPCR but were

279 not detectable in PCR. This may be due to the limitation of UV visualization because some

280 bands in agarose gels were not visible clearly under UV light. Relative abundance of intI1 in PL2 
281 and SL5 samples was both above average in qPCR but intI1 gene in these samples was not 282 detected in PCR.

283 The results showed that sulII, ermF, tnpA, and intII concentrations were not significantly 284 different among five manure conditions (FP, CP, FM, PL, SL), and only one gene- tet $W$, was 285 found at a significantly lower concentration in CP compared with the FM and PL. Previous 286 studies showed various responses of ARGs to biological treatment methods such as anaerobic 287 lagoons and composting (Zhang et al., 2021). This may be due to different experimental 288 conditions and complex microbial ecologies involved (Pruden et al. 2013). McKinney et al. 289 (2010) observed reductions of tet ARGs but increases of sul ARGs in anaerobic lagoons. Zhang 290 et al. (2017) found that absolute abundances of 13 out of 14 ARGs and two integrase genes 291 increased after 52 days of anaerobic digestion of swine manure. Sun et al. (2016) stated that 4 292 out of 10 detected ARGs declined during dairy manure anaerobic digestion under $20^{\circ} \mathrm{C}$. 293 Storteboom et al. (2007) reported reduction of tet $\mathrm{O}$ but increase of tet $W$ during horse manure 294 composting process. Previous studies reported a higher decrease of cultivated antibiotic resistant 295 bacteria in composting process compared to lagoon system (Wang et al. 2012). While IS6, 296 family members of bacterial and archaeal insertion sequences are known to play crucial role in 297 spreading antibiotic-resistance genes, overproduction inhibition phenomenon presents challenges 298 (Munoz-Lopez and Garcia-Perez, 2010; Harmer and Hall, 2019). The overproduction and 299 inhibition phenomenon is the property of some transposases where they display lower activity at 300 higher concentrations; this could affect the detection of transposases as the concentration must be 301 taken into account when evaluating impacts of these genes (Harmer and Hall, 2019; Harmer and 302 Hall, 2020). A pitfall in the current study is that the primer used to screentransposons tnpA was 303 specific to those previously observed in the IS6, and may have limited complete identification of 
304 all potential tnpA in the samples; a general concern with transposons is the potential role they

305 may play on dissemination of various ARGs, and further studies would need to be conducted to 306 specifically quantify their corroboration towards this effect,

307 It was noticed that average sulII, tet W, and intII concentrations identified in this study 308 were lower than previous findings. As an example, McKinney et al. (2010) reported sulII and 309 tet $W$ of $\sim 10^{-1}$ and $10^{-2}$ copies/16S rRNA respectively in a dairy lagoon samples in Colorado.

310 Dungan et al. (2018) reported intIl gene copies of $10^{-2} / 16 \mathrm{~S}$ rRNA gene in the dairy wastewater

311 in Idaho. Differences in ARG levels may be due to site-specific physical/chemical conditions,

312 manure handing methods, and historical intensity of antibiotic use (He et al. 2020). However, tet

313 and sul were reported to be the most abundant ARGs in livestock waste (He et al. 2020), which is

314 aligned to the findings of this study.

315 Cooccurrence of ARGs, MGEs, and microbial communities

316 Integrons and transposons have been reported as responsible for the acquisition and 317 dissemination of ARGs by HGT, which indicates that HGT could be a potential mechanism for

318 the spread and dissemination of specific ARGs (Han et al. 2016; Sandberg and LaPara 2016). In 319 addition, the sulII gene was reported on a broad-host-range (BHR) plasmid RSF1010 (Rådström and Swedberg 1988; Yau et al. 2010), and BHR plasmids are of considerable interest because they are reported not only in single bacterial species but also members of different taxonomic 322 group, and play an important role in HGT. Existing knowledge in terms of how anaerobic

323 processes influences ARGs is weak, particularly the effects of anaerobic digesters treating dairy 324 manure on ARGs of manure is not well understood. Preliminary research such as a study by Huang et al. (2019) investigated the abundance of ARGs and transposase genes during anaerobic process, and authors found a reduction in ARG and transposons genes during $\mathrm{AD}$ of pig manure. 
327 These findings suggest that transposons genes could be correlated with ARGs. Correlations

328 between other genes were not significant, and this may be due to resistance genes not located in 329 integrons/transposons and non-specific selection agents in the manure (Andersson and Hughes 330 2010; Di Cesare et al. 2016; McKinney et al. 2010).

331 While assessing the presence of ARGs, it is crucial to understand the correlation between 332 ARGs and various microbial species. Previous studies indicate that gram-negative bacteria such 333 as Psychrobacter and Pseudomonas, which are abundant in the environment and able to tolerate 334 both cold and hot environment, showed correlation with ARGs and MGE. As an example, one 335 of the species in Pseudomonas genus, Pseudomonas aeruginosa, is an opportunistic pathogen 336 that causes infections in humans with a high mortality rate. Presence of ermF in Pseudomonas 337 could compromise clinical treatment by $\mathrm{MLS}_{\mathrm{B}}$ antibiotics. Pseudomonas is resistant to a variety 338 of antimicrobials due to multidrug efflux pumps, chromosomal mutations and the acquisition of 339 resistance genes via HGT (Poole, 2011). These findings are important because the presence of 340 ARGs in environmental bacteria have the potential to be received by human and animal

341 pathogens through HGT, which increases the risk to public and animal healths via antimicrobial 342 resistance (AMR) exposure.

343 While these results indicate the possibility of putative microorganisms hosting ARGs,

344 additional studies are needed for strengthening the findings considering a preliminary nature of 345 this study. A previous study by Flores-Orozco et al. (2020) identified more than 180 unique 346 antibiotic-resistance genes in dairy manure, and changes in ARGs levels were found to be related 347 with the shifts in the microbial community. Detailed bioinformatic analysis was conducted to 348 evaluate the co-occurrence of microbial groups and ARGs results revealed the presence of 349 potential microbial ARG hosts. 
350 Many ARGs such as tetX, sul1, sul2, and tetG were dominant in various farm's soils (Duan et

351 al., 2019). Studies (Duan et al., 2019; Zhang et al., 2021) focused on evaluating the impacts of

352 manure on soil's ARGs, and anaerobic digestion process effects on the reduction of ARGs in

353 manure suggested that cropland's soil receiving manure showed more than 2 times higher ARGs

354 compared to the soil without manure. Manure treatment process such as anaerobic digestion was

355 found to be effective in reducing ARGs levels in manure, and changes in microbial community

356 during anaerobic digestion resulted in reduced ARGs level (Flores-Orozco et al., 2020; Zhang et

357 al., 2021).

358 One of the major limitations of this study is fewer sample numbers and samples from

359 limited dairy farms. Further, manure management practices change from one farm to another

360 substantially, which pose challenges in comparing the microbial and ARGs data among farms.

361 Understanding the deviation in characteristics of ARGs and microbial community within and

362 between farms with similar management practices can provide greater understanding of

363 temporal changes in ARGs present in liquid manure versus solid manure.

364

365 Conclusions

366 In this research, we studied the prevalence of ARGs and MGEs in flushed manure,

367 primary lagoon manure, secondary lagoon manure, fresh pile manure, and compost pile manure.

368 Manure samples were obtained from multiple dairy farms located in Central Valley, California.

369 Prevalence of genes varied among sample types, but all of the studied genes were detectable in

370 different manure types. Among five genes quantified, only tet $W$ was found at significantly lower

371 concentration in compost pile comparing with flushed manure (adj. $p=0.02$ ) and primary lagoon

372 samples (adj. $p=0.02)$. Results of this study showed that ARGs are widely present in liquid

373 (lagoon samples) and solid dairy farm manure (fresh and compost piles). Different manure 
374

375

376

377

378

379

380

381

382

383

384

385

386

387

388

389

390

391

392

393

394

395

396

397

398

399

400

401

402

403

404

405

406

407

408

409

410

411

412

413

414

415

management such as liquid-solid separation, piling, and lagoon storage may not have significant impacts on ARG and MGE reductions.

\section{Acknowledgements}

Authors thank Division of Agriculture and Natural Resources (ANR), University of California, Davis, for supporting this study. Authors also thank Dr. Noelia Silva Del Rio, Dr. Alejandro Castillo, and Betsy Karle, University of California Cooperative Extension, California for their support in sample collection.

\section{References}

Alexander TW, Yanke JL, Reuter T, Topp E, Read RR, Selinger BL, and McAllister TA. 2011. Longitudinal characterization of antimicrobial resistance genes in feces shed from cattle fed different subtherapeutic antibiotics. BMC Microbiology 11:19. DOI: 10.1186/14712180-11-19

Allen HK, Donato J, Wang HH, Cloud-Hansen KA, Davies J, and Handelsman J. 2010. Call of the wild: antibiotic resistance genes in natural environments. Nature Reviews: Microbiology 8:251-259. DOI: 10.1038/nrmicro2312

Aminov R, Garrigues-Jeanjean N, and Mackie R. 2001. Molecular ecology of tetracycline resistance: development and validation of primers for detection of tetracycline resistance genes encoding ribosomal protection proteins. Applied and Environmental Microbiology 67:22-32. DOI: 10.1128/AEM.67.1.22-32.2001

Andersson DI, and Hughes D. 2010. Antibiotic resistance and its cost: is it possible to reverse resistance? Nature Reviews Microbiology 8:260. DOI: 10.1038/nrmicro2319

Barlow RS, Pemberton JM, Desmarchelier PM, and Gobius KS. 2004. Isolation and characterization of integron-containing bacteria without antibiotic selection. Antimicrob Agents Chemother 48: 838842.

Baquero F, Martínez J-L, and Cantón R. 2008. Antibiotics and antibiotic resistance in water environments. Current Opinion in Biotechnology 19:260-265. DOI: 10.1016/j.copbio.2008.05.006

Bennett P. 2008. Plasmid encoded antibiotic resistance: acquisition and transfer of antibiotic resistance genes in bacteria. British Journal of Pharmacology 153:S347-S357. DOI: 10.1038/sj.bjp.0707607

Burch TR, Sadowsky MJ, and LaPara TM. 2016. Modeling the fate of antibiotic resistance genes and class 1 integrons during thermophilic anaerobic digestion of municipal wastewater solids. Applied and Environmental Microbiology 100:1437-1444. DOI: 10.1007/s00253015-7043-X

CARB. 2017. California Dairy 101: Overview of dairy farming and manure methane reduction opportunities. Available at https://ww3.arb.ca.gov/cc/dairy/documents/08-21-17/dsg1dairy-101-presentation.pdf (accessed 1 March 2019) 
416

417

418

419

420

421

422

423

424

425

426

427

428

429

430

431

432

433

434

435

436

437

438

439

440

441

442

443

444

445

446

447

448

449

450

451

452

453

454

455

456

457

458

459

460
CDC. 2013. Antibiotic resistance threats in the United States. Available at https://www.cdc.gov/drugresistance/threat-report-2013/pdf/ar-threats-2013-508.pdf (accessed 1 March 2019)

CDC. 2019. Antibiotic resistance threats in the United States. Available at https://www.cdc.gov/drugresistance/pdf/threats-report/2019-ar-threats-report-508.pdf (accessed 1 March 2019

Chen J, Yu Z, Michel FC, Wittum T, and Morrison M. 2007. Development and application of real-time PCR assays for quantification of erm genes conferring resistance to macrolideslincosamides-streptogramin B in livestock manure and manure management systems. Applied and Environmental Microbiology 73:4407-4416. DOI: 10.1128/AEM.02799-06

Cheng W, Chen H, Su C, and Yan S. 2013. Abundance and persistence of antibiotic resistance genes in livestock farms: A comprehensive investigation in eastern China. Environment International 61:1-7. DOI: 10.1016/j.envint.2013.08.023

D'Costa VM, McGrann KM, Hughes DW, and Wright GD. 2006. Sampling the antibiotic resistome. Science 311:374-377. DOI: 10.1126/science.1120800

Di Cesare A, Eckert EM, D'Urso S, Bertoni R, Gillan DC, Wattiez R, and Corno G. 2016. Cooccurrence of integrase 1, antibiotic and heavy metal resistance genes in municipal wastewater treatment plants. Water Research 94:208-214. DOI: 10.1016/j.watres.2016.02.049

Duan M, Gu J, Wang X, Li Y, Zhang R, Hu T, and Zhou B. 2019. Factors that affect the occurrence and distribution of antibiotic resistance genes in soils from livestock and poultry farms. Ecotoxicology and Environmental Safety, 180, 114-122. https://doi.org/10.1016/j.ecoenv.2019.05.005

Dungan RS, McKinney CW, and Leytem AB. 2018. Tracking antibiotic resistance genes in soil irrigated with dairy wastewater. Science of The Total Environment 635:1477-1483. DOI: 10.1016/j.scitotenv.2018.04.020

FDA. 2012. Drug Use Review. Available at https://www.fda.gov/downloads/drugs/drugsafety/informationbydrugclass/ucm319435.pd f (accessed 1 August 2020).

FDA. 2019. Summary Report on Antimicrobials Sold or Distributed for Use in Food-Producing Animals. Available at https://www.fda.gov/media/133411/download (Accessed 1 August 2020).

Flores-Orozco D, Patidar R, Levin DB, Sparling R, Kumar A, and Çiçek N. 2020. Effect of ceftiofur on mesophilic anaerobic digestion of dairy manure and the reduction of the cephalosporin-resistance gene cmy-2. Bioresource Technology 301:122729. DOI: 10.1016/j.biortech.2019.122729

Frieri M, Kumar K, and Boutin A. 2017. Antibiotic resistance. Journal of Infection and Public Health 10:369-378. DOI: 10.1016/j.jiph.2016.08.007

Garder JL, Moorman TB, and Soupir ML. 2014. Transport and persistence of tylosin-resistant Enterococci, genes, and tylosin in soil and drainage water from fields receiving swine manure. Journal of Environmental Quality 43:1484-1493. DOI: 10.2134/jeq2013.09.0379

Ghosh S, and LaPara TM. 2007. The effects of subtherapeutic antibiotic use in farm animals on the proliferation and persistence of antibiotic resistance among soil bacteria. ISME J 1:191-203. DOI: 10.1038/ismej.2007.31

Peer] reviewing PDF | (2020:12:56611:4:0:NEW 6 Oct 2021) 
461 Gogarten JP, and Townsend JP. 2005. Horizontal gene transfer, genome innovation and $462 \quad$ evolution. Nature Reviews: Microbiology 3:679-687. DOI: 10.1038/nrmicro1204

463

464

465

466

467

468

469

470

471

472

473

474

475

476

477

478

479

480

481

482

483

484

485

486

487

488

489

490

491

492

493

494

495

496

497

498

499

500

501

502

503

504

505

506

507

Gou M, Hu H-W, Zhang Y-J, Wang J-T, Hayden H, Tang Y-Q, and He J-Z. 2018. Aerobic composting reduces antibiotic resistance genes in cattle manure and the resistome dissemination in agricultural soils. Science of The Total Environment 612:1300-1310. DOI: 10.1016/j.scitotenv.2017.09.028

Guardabassi L, Schwarz S, and Lloyd DH. 2004. Pet animals as reservoirs of antimicrobialresistant bacteria. Journal of Antimicrobial Chemotherapy 54:321-332. DOI: $10.1093 / \mathrm{jac} / \mathrm{dkh} 332$

Han X-M, Hu H-W, Chen Q-L, Yang L-Y, Li H-L, Zhu Y-G, Li X-Z, and Ma Y-B. 2018. Antibiotic resistance genes and associated bacterial communities in agricultural soils amended with different sources of animal manures. Soil Biology and Biochemistry 126:91-102. DOI: 10.1016/j.soilbio.2018.08.018

Han X-M, Hu H-W, Shi X-Z, Wang J-T, Han L-L, Chen D, and He J-Z. 2016. Impacts of reclaimed water irrigation on soil antibiotic resistome in urban parks of Victoria, Australia. Environmental Pollution 211:48-57. DOI: 10.1016/j.envpol.2015.12.033

Harmer CJ, Hall RM. 2019. An analysis of the IS6/IS26 family of insertion sequences: is it a single family? Microb Genom. 5(9):e000291.

Harmer CJ, Hall RM. 2020. IS26 family members IS257 and IS1216 also form cointegrates by copy-in and targeted conservative routes. mSphere 5:e0811-19. https://doi.org/10.1128/mSphere.0081119.

He Y, Yuan Q, Mathieu J, Stadler L, Senehi N, Sun R, and Alvarez PJJ. 2020. Antibiotic resistance genes from livestock waste: occurrence, dissemination, and treatment. $n p j$ Clean Water 3:4. DOI: 10.1038/s41545-020-0051-0

Hickman AB, Dyda F. 2016. DNA Transposition at Work. Chem Rev. 116, 12758-12784

Howes SA. 2017. The effect of thermophilic anaerobic digestion on ceftiofur and antibiotic resistant gene concentrations in dairy manure. Master Thesis, Virginia Tech.

Hu H-W, Han X-M, Shi X-Z, Wang J-T, Han L-L, Chen D, and He J-Z. 2015. Temporal changes of antibiotic resistance genes and bacterial communities in two contrasting soils treated with cattle manure. FEMS Microbiology Ecology. DOI: 10.1093/femsec/fiv169

Huang X, Zheng J, Tian S, Liu C, Liu L, Wei L, Fan H, Zhang T, Wang L, Zhu G, and Xu K. 2019. Higher temperatures do not always achieve better antibiotic resistance gene removal in anaerobic digestion of swine manure. Applied and Environmental Microbiology 85:e2878-02818. DOI: 10.1128/aem.02878-18

Hurst JJ, Oliver JP, Schueler J, Gooch C, Lansing S, Crossette E, Wigginton K, Raskin L, Aga DS, and Sassoubre LM. 2019. Trends in Antimicrobial Resistance Genes in Manure Blend Pits and Long-Term Storage Across Dairy Farms with Comparisons to Antimicrobial Usage and Residual Concentrations. Environmental Science \& Technology 53:2405-2415. DOI: 10.1021/acs.est.8b05702

Jjemba PK. 2002. The potential impact of veterinary and human therapeutic agents in manure and biosolids on plants grown on arable land: A review. Agriculture, Ecosystems and Environment, 93, 267-278. https://doi.org/10.1016/S0167-8809(01)00350-4

Kaffka S, Barzee T, El-Mashad H, Williams R, Zicari S, and Zhang R. 2016. Evaluation of Dairy Manure Management Practices for Greenhouse Gas Emissions Mitigation in California. Contract 14:456.

Peer] reviewing PDF | (2020:12:56611:4:0:NEW 6 Oct 2021) 
508 Klindworth A, Pruesse E, Schweer T, Peplies J, Quast C, Horn M, and Glöckner FO. 2012.

509

510

511

512

513

514

515

516

517

518

519

520

521

522

523

524

525

526

527

528

529

530

531

532

533

534

535

536

537

538

539

540

541

542

543

544

545

546

547

548

549

550

551

552

553
Evaluation of general $16 \mathrm{~S}$ ribosomal RNA gene PCR primers for classical and nextgeneration sequencing-based diversity studies. Nucleic Acids Research 41:e1-e1. DOI: 10.1093/nar/gks808

Koike S, Aminov RI, Yannarell AC, Gans HD, Krapac IG, Chee-Sanford JC, and Mackie RI. 2010. Molecular Ecology Of Macrolide-Lincosamide-Streptogramin B Methylases in Waste Lagoons and Subsurface Waters Associated with Swine Production. Microbial Ecology 59:487-498. DOI: 10.1007/s00248-009-9610-0

Kumar K, Gupta SC, Baidoo S, Chander Y, and Rosen CJ. 2005. Antibiotic uptake by plants from soil fertilized with animal manure. Journal of environmental quality 34:2082-2085. DOI: $10.2134 /$ jeq2005.0026

Ma Z, Wu H, Zhang K, Xu X, Wang C, Zhu W, and Wu W. 2018. Long-term low dissolved oxygen accelerates the removal of antibiotics and antibiotic resistance genes in swine wastewater treatment. Chemical Engineering Journal 334:630-637. DOI: 10.1016/j.cej.2017.10.051

Marti E, Jofre J, and Balcazar JL. 2013. Prevalence of antibiotic resistance genes and bacterial community composition in a river influenced by a wastewater treatment plant. PloS One 8:e78906. DOI: 10.1021/es504157v

McKinney CW, Loftin KA, Meyer MT, Davis JG, and Pruden A. 2010. Tet and sul antibiotic resistance genes in livestock lagoons of various operation type, configuration, and antibiotic occurrence. Environmental Science \& Technology 44:6102-6109. DOI: 10.1021/es9038165

Meyer D, Price PL, Rossow HA, Silva-del-Rio N, Karle BM, Robinson PH, DePeters EJ, and Fadel JG. 2011. Survey of dairy housing and manure management practices in California. Journal of Dairy Science 94:4744-4750. DOI: 10.3168/jds.2010-3761

Muñoz-López M, and García-Pérez JL. 2010. DNA transposons: nature and applications in genomics. Curr. Genomics 11, 115-128

Muyzer G, De Waal EC, and Uitterlinden AG. 1993. Profiling of complex microbial populations by denaturing gradient gel electrophoresis analysis of polymerase chain reactionamplified genes coding for 16S rRNA. Applied and Environmental Microbiology 59:695700.

Pandey P, Chiu C, Miao M, Wang Y, Settles M, del Rio NS, Castillo A, Souza A, Pereira R, and Jeannotte R. 2018. 16S rRNA analysis of diversity of manure microbial community in dairy farm environment. PloS One 13:e0190126. DOI: 10.1371/journal.pone.0190126

Pang Z, Raudonis R, Glick BR, Lin T-J, and Cheng Z. 2019. Antibiotic resistance in Pseudomonas aeruginosa: mechanisms and alternative therapeutic strategies. Biotechnology Advances 37:177-192. DOI: 10.1016/j.biotechadv.2018.11.013

Parashar D, Chauhan D, Sharma V, and Katoch V. 2006. Applications of real-time PCR technology to mycobacterial research. Indian Journal of Medical Research 124:385.

Pei R, Cha J, Carlson KH, and Pruden A. 2007. Response of antibiotic resistance genes (ARG) to biological treatment in dairy lagoon water. Environmental science \& technology 41:51085113. DOI: $10.1021 / \mathrm{es} 070051 \mathrm{x}$

Pei R, Kim SC, Carlson KH, and Pruden A. 2006. Effect of river landscape on the sediment concentrations of antibiotics and corresponding antibiotic resistance genes (ARG). Water Research 40:2427-2435. DOI: 10.1016/j.watres.2006.04.017

Peer) reviewing PDF | (2020:12:56611:4:0:NEW 6 Oct 2021) 
554

555

556

557

558

559

560

561

562

563

564

565

566

567

568

569

570

571

572

573

574

575

576

577

578

579

580

581

582

583

584

585

586

587

588

589

590

591

592

593

594

595

596

597

598

Poole K. 2011. Pseudomonas aeruginosa: resistance to the max. Frontiers in Microbiology 2:6565. DOI: $10.3389 /$ fmicb.2011.00065

Pruden A, Larsson DJ, Amézquita A, Collignon P, Brandt KK, Graham DW, Lazorchak JM, Suzuki S, Silley P, and Snape JR. 2013. Management options for reducing the release of antibiotics and antibiotic resistance genes to the environment. Environmental health perspectives 121:878. DOI: 10.1289/ehp.1206446

Rådström P, and Swedberg G. 1988. RSF1010 and a conjugative plasmid contain sulII, one of two known genes for plasmid-borne sulfonamide resistance dihydropteroate synthase. Antimicrob Agents Chemother 32:1684-1692. DOI: 10.1128/aac.32.11.1684

Roberts RR, Hota B, Ahmad I, Scott RD, Foster SD, Abbasi F, Schabowski S, Kampe LM, Ciavarella GG, and Supino M. 2009. Hospital and societal costs of antimicrobial-resistant infections in a Chicago teaching hospital: implications for antibiotic stewardship. $J$ Clinical infectious diseases 49:1175-1184. DOI: 10.1086/605630

Sandberg KD, and LaPara TM. 2016. The fate of antibiotic resistance genes and class 1 integrons following the application of swine and dairy manure to soils. FEMS Microbiology Ecology 92. DOI: 10.1093/femsec/fiw001

Selvam A, Xu D, Zhao Z, and Wong JW. 2012. Fate of tetracycline, sulfonamide and fluoroquinolone resistance genes and the changes in bacterial diversity during composting of swine manure. Bioresource Technology 126:383-390. DOI: 10.1016/j.biortech.2012.03.045

Storteboom HN, Kim S-C, Doesken KC, Carlson KH, Davis JG, and Pruden A. 2007. Response of antibiotics and resistance genes to high-intensity and low-intensity manure management. Journal of Environmental Quality 36:1695-1703. DOI: 10.2134/jeq2007.0006

Sun W, Qian X, Gu J, Wang X-J, and Duan M-L. 2016. Mechanism and effect of temperature on variations in antibiotic resistance genes during anaerobic digestion of dairy manure. Scientific Reports 6:1-9. doi:10.1038/srep30237

UCS. 2001. Hogging it!: Estimates of antimicrobial abuse in livestock. Available at https://www.ucsusa.org/food_and agriculture/our-failing-food-system/industrialagriculture/hogging-it-estimates-of.html\#.W77eXi Mz2Q (accessed 1 August 2020).

USDA. 2012. Census of Agriculture. USDA National Agricultural Statistics Service. Available at https://www.nass.usda.gov/Publications/AgCensus/2012/ (accessed 1 March 2019).

USDA. 2016. National Agricultural Statistics Service. Available at https://www.nass.usda.gov/Charts_and_Maps/Cattle/ (accessed 1 March 2019).

Wang L, Oda Y, Grewal S, Morrison M, Michel FC, and Yu Z. 2012. Persistence of resistance to erythromycin and tetracycline in swine manure during simulated composting and lagoon treatments. Microbial Ecology 63:32-40. DOI: 10.1007/s00248-011-9921-9

Wind L, Krometis L-A, Hession WC, Chen C, Du P, Jacobs K, Xia K, and Pruden A. 2018. Fate of pirlimycin and antibiotic-resistant fecal coliforms in field plots amended with dairy manure or compost during vegetable cultivation. Journal of Environmental Quality 47:436-444. DOI: $10.2134 /$ jeq2017.12.0491.

Xia J, Sinelnikov IV, Han B, and Wishart DS. 2015. MetaboAnalyst 3.0 - making metabolomics more meaningful. Nucleic acids research 43:W251-W257. DOI: 10.1093/nar/gkv380

Yau S, Liu X, Djordjevic SP, and Hall RM. 2010. RSF1010-like plasmids in Australian Salmonella enterica serovar Typhimurium and origin of their sul2-strA-strB antibiotic 
599

600

601

602

603

604

605

606

607

608

609

610

611

612

613

614

615

616

617

618

resistance gene cluster. Microbial Drug Resistance 16:249-252. DOI:

10.1089/mdr.2010.0033

Zaman SB, Hussain MA, Nye R, Mehta V, Mamun KT, and Hossain N. 2017. A review on antibiotic resistance: alarm bells are ringing. Cureus 9. DOI: 10.7759/cureus. 1403

Zhang R, Wang X, Gu J, and Zhang Y. 2017. Influence of zinc on biogas production and antibiotic resistance gene profiles during anaerobic digestion of swine manure. Bioresource Technology 244:63-70. DOI: 10.1016/j.biortech.2017.07.032

Zhang Q, Xu J, Wang X, Zhu W, Pang X, and Zhao J. 2021. Changes and distributions of antibiotic resistance genes in liquid and solid fractions in mesophilic and thermophilic anaerobic digestion of dairy manure. Bioresource Technology, 320, 124372. https://doi.org/10.1016/j.biortech.2020.124372

Zhao X, Wang J, Zhu L, Ge W, and Wang J. 2017. Environmental analysis of typical antibioticresistant bacteria and ARGs in farmland soil chronically fertilized with chicken manure. Science of the Total Environment 593:10-17. DOI: 10.1016/j.scitotenv.2017.03.062

Zhu YG, Johnson TA, Su JQ, Qiao M, Guo GX, Stedtfeld RD, Hashsham SA, and Tiedje JM. 2013. Diverse and abundant antibiotic resistance genes in Chinese swine farms. Proceedings of the National Academy of Sciences of the United States of America 110:3435-3440. DOI: 10.1073/pnas.1222743110. 


\section{Table $\mathbf{1}$ (on next page)}

Synthetic oligonucleotides 
Table 1 Synthetic oligonucleotides used in this study

\begin{tabular}{|c|c|c|c|c|c|c|}
\hline Primer & $\begin{array}{l}\text { Target } \\
\text { gene }\end{array}$ & Sequences (direction $5^{\prime}-3^{\prime}$ ) & $\begin{array}{l}\text { Traditional } \\
\text { PCR } \\
\text { annealing } \\
\text { temp }\left({ }^{\circ} \mathbf{C}\right) \\
\end{array}$ & $\begin{array}{l}\text { qPCR } \\
\text { annealing } \\
\text { temp }\left({ }^{\circ} \mathrm{C}\right)\end{array}$ & $\begin{array}{l}\text { Amplicon } \\
\text { size (bp) }\end{array}$ & Reference \\
\hline $\begin{array}{l}\text { sulI- } \\
\text { FW } \\
\text { sulI-RV }\end{array}$ & sulI & $\begin{array}{l}\text { CGCACCGGAAACATCGCTGCAC } \\
\text { TGAAGTTCCGCCGCAAGGCTCG }\end{array}$ & 60 & 60 & 163 & \\
\hline $\begin{array}{l}\text { sulII- } \\
\text { FW } \\
\text { sulII- } \\
\text { RV }\end{array}$ & sullI & $\begin{array}{l}\text { TCCGGTGGAGGCCGGTATCTGG } \\
\text { CGGGAATGCCATCTGCCTTGAG }\end{array}$ & 60 & 60 & 191 & \\
\hline $\begin{array}{l}\text { sulIII- } \\
\text { FW } \\
\text { sulIII- } \\
\text { RV }\end{array}$ & sulIII & $\begin{array}{l}\text { TCCGTTCAGCGAATTGGTGCAG } \\
\text { TTCGTTCACGCCTTACACCAGC }\end{array}$ & 60 & 60 & 128 & $\begin{array}{l}\text { (Pei et al. } \\
\text { 2006) }\end{array}$ \\
\hline $\begin{array}{l}\text { sulA- } \\
\text { FW } \\
\text { sulA- } \\
\text { RV }\end{array}$ & sulA & $\begin{array}{l}\text { TCTTGAGCAAGCACTCCAGCAG } \\
\text { TCCAGCCTTAGCAACCACATGG }\end{array}$ & 60 & 60 & 299 & \\
\hline $\begin{array}{l}\text { tetW- } \\
\text { FW } \\
\text { tetW- } \\
\text { RV } \\
\text { tetO- } \\
\text { FW } \\
\text { tetO- } \\
\text { RV } \\
\end{array}$ & tet $W$ & $\begin{array}{l}\text { GAGAGCCTGCTATATGCCAGC } \\
\text { GGGCGTATCCACAATGTTAAC } \\
\text { ACGGARAGTTTATTGTATACC } \\
\text { TGGCGTATCTATAATGTTGAC }\end{array}$ & 55 & 53.9 & 168 & $\begin{array}{l}\text { (Aminov et } \\
\text { al. 2001) }\end{array}$ \\
\hline $\begin{array}{l}\text { ermB- } \\
\text { FW } \\
\text { ermB- } \\
\text { RV }\end{array}$ & ermB & $\begin{array}{l}\text { GGTTGCTCTTGCACACTCAAG } \\
\text { CAGTTGACGATATTCTCGATTG }\end{array}$ & 55 & 51.2 & 191 & $\begin{array}{l}\text { (Koike et } \\
\text { al. 2010) }\end{array}$ \\
\hline $\begin{array}{l}\text { ermF- } \\
189 \mathrm{f} \\
\text { ermF- } \\
497 \mathrm{r}\end{array}$ & ermF & $\begin{array}{l}\text { CGACACAGCTTTGGTTGAAC } \\
\text { GGACCTACCTCATAGACAAG }\end{array}$ & 55 & 51.4 & 309 & $\begin{array}{l}\text { (Chen et al. } \\
\text { 2007) }\end{array}$ \\
\hline $\begin{array}{l}\text { HS463a } \\
\text { HS464 } \\
\end{array}$ & intI1 & $\begin{array}{l}\text { CTGGATTTCGATCACGGCACG } \\
\text { ACATGCGTGTAAATCATCGTCG }\end{array}$ & 60 & 55.7 & 473 & $\begin{array}{l}\text { (Barlow et } \\
\text { al., 2004) }\end{array}$ \\
\hline $\begin{array}{l}\operatorname{tnpA-} \\
04 \mathrm{~F} \\
\operatorname{tnpA-} \\
04 \mathrm{R}\end{array}$ & $\operatorname{tnp} A-04$ & $\begin{array}{l}\text { CCGATCACGGAAAGCTCAAG } \\
\text { GGCTCGCATGACTTCGAATC }\end{array}$ & 60 & 56 & 101 & $\begin{array}{l}\text { (Zhu et al. } \\
\text { 2013) }\end{array}$ \\
\hline $357 \mathrm{~F}$ & $\begin{array}{l}16 \mathrm{~S} \\
\text { rRNA } \\
\text { gene }\end{array}$ & CCTACGGGAGGCAGCAG & 60 & 56 & 193 & $\begin{array}{l}\text { (Muyzer et } \\
\text { al. 1993) }\end{array}$ \\
\hline
\end{tabular}


1

Peer) reviewing PDF | (2020:12:56611:4:0:NEW 6 Oct 2021) 
Table 2 (on next page)

Detection of resistance gene families 
Table 2 Detection of resistance gene families in dairy manure

\begin{tabular}{|c|c|c|c|c|c|c|c|c|c|c|c|c|}
\hline & Sample ID & sulI & sullI & sulIII & sulA & tetO & tetW & ermB & ermF & $\operatorname{tnp} A$ & intI1 & Percentage \\
\hline 1 & FP1 & + & + & + & + & + & + & + & + & + & + & $100 \%$ \\
\hline 2 & FP2 & + & + & - & - & - & + & - & - & + & + & $50 \%$ \\
\hline 3 & FP3 & + & + & - & - & + & + & - & + & + & - & $60 \%$ \\
\hline 4 & FP4 & + & + & - & - & - & + & + & + & + & + & $70 \%$ \\
\hline 5 & FP5 & + & + & + & + & + & + & + & + & + & + & $100 \%$ \\
\hline 6 & FP6 & + & + & + & - & + & + & + & + & + & + & $90 \%$ \\
\hline 7 & FP7 & + & + & + & + & + & + & + & + & + & + & $100 \%$ \\
\hline 8 & $\mathrm{CP} 1$ & + & + & - & - & - & + & - & + & + & + & $60 \%$ \\
\hline 9 & $\mathrm{CP} 2$ & + & + & + & - & + & + & - & + & + & - & $70 \%$ \\
\hline 10 & $\mathrm{CP} 3$ & - & - & - & - & - & - & - & - & - & + & $10 \%$ \\
\hline 11 & $\mathrm{CP} 4$ & + & + & + & - & + & + & + & + & + & + & $90 \%$ \\
\hline 12 & CP5 & - & + & - & - & - & - & - & - & - & + & $20 \%$ \\
\hline 13 & CP6 & + & + & - & - & - & + & - & - & + & - & $40 \%$ \\
\hline 14 & CP7 & - & + & - & - & - & + & - & + & + & - & $40 \%$ \\
\hline 15 & FM1 & + & + & - & - & - & + & + & + & + & + & $70 \%$ \\
\hline 16 & FM2 & + & + & - & - & - & + & + & + & + & + & $70 \%$ \\
\hline 17 & FM3 & + & + & + & - & + & + & + & + & + & + & $90 \%$ \\
\hline 18 & FM4 & + & + & - & - & + & + & + & + & + & + & $80 \%$ \\
\hline 19 & FM5 & + & + & - & - & + & + & + & + & + & + & $80 \%$ \\
\hline 20 & FM6 & + & + & - & - & + & + & + & + & + & + & $80 \%$ \\
\hline 21 & PL1 & + & + & - & - & + & + & + & + & + & + & $80 \%$ \\
\hline 22 & PL2 & - & - & - & - & - & - & - & - & - & - & 0 \\
\hline 23 & PL3 & + & + & + & - & + & + & + & + & + & + & $90 \%$ \\
\hline 24 & PL4 & + & + & + & - & + & + & + & + & + & + & $90 \%$ \\
\hline 25 & PL5 & + & + & + & - & + & + & + & + & + & + & $90 \%$ \\
\hline 26 & PL6 & + & + & - & - & + & + & + & + & + & + & $80 \%$ \\
\hline 27 & PL7 & + & + & - & - & + & + & + & + & + & + & $80 \%$ \\
\hline 28 & PL8 & + & + & + & - & + & + & + & + & + & + & $90 \%$ \\
\hline 39 & SL1 & + & + & - & - & - & + & + & + & + & + & $70 \%$ \\
\hline 30 & SL2 & + & + & + & - & + & + & + & + & + & + & $90 \%$ \\
\hline 31 & SL3 & + & + & + & - & - & + & + & + & + & + & $80 \%$ \\
\hline 32 & SL4 & + & + & + & + & + & + & + & + & + & + & $100 \%$ \\
\hline 33 & SL5 & + & + & - & - & + & + & - & + & + & - & $60 \%$ \\
\hline
\end{tabular}
+ : present; -: absent.

FP: Fresh Pile; CP: Compost Pile; FM: Flushed manure; PL: Primary Lagoon; SL: Secondary 
Figure 1

Manure flow 


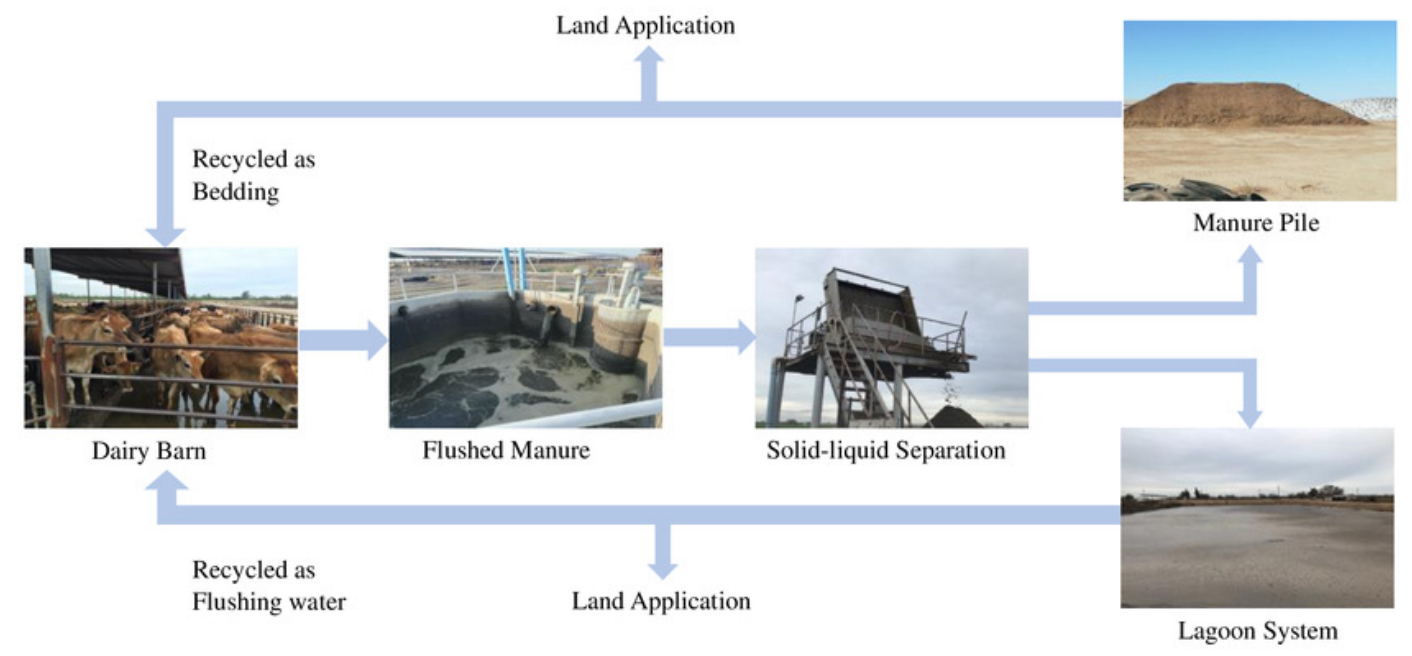

Figure 1 Typical processing of flushed manure in dairy farms in Central Valley California (source: Pandey et al. 2019). 
Figure 2

Copies of Resistance genes 

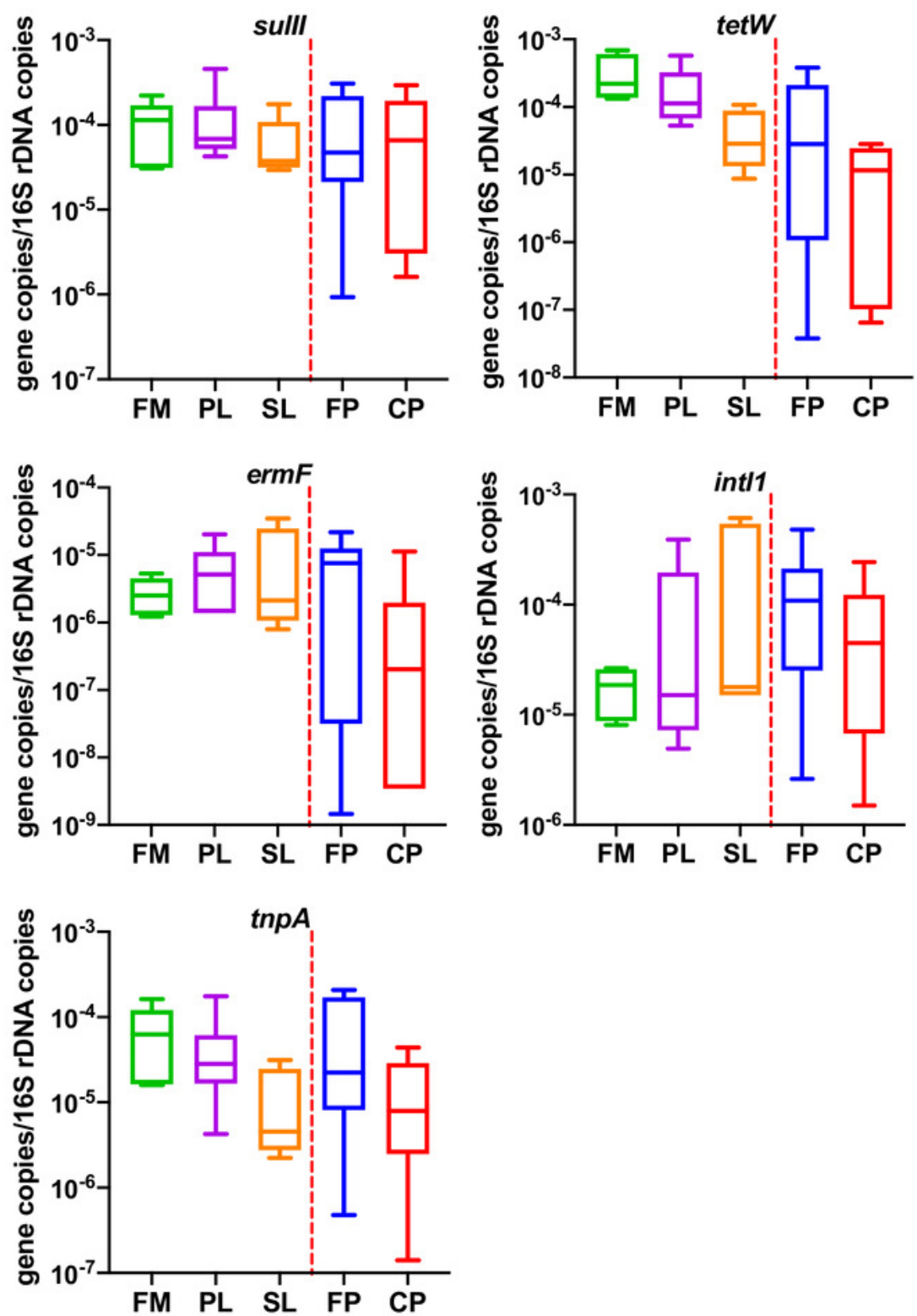

Figure 2 Copies of resistance related genes normalized to the number of bacterial 16S rRNA gene genes in different dairy manure. $\mathrm{X}$-axis labels indicate the type of dairy treatments, rectangular boxes indicate the interquartile range of the data; median value is indicated by the horizontal line inside the box. Whiskers show min to max of data. Extreme outliers (< Q1 - 3 IQ or $>$ Q3 + 3 IQ) were removed and shown as "--" in Table 3. FM: Flushed Manure; PL: Primary Lagoon; SL: Secondary Lagoon; FP: Fresh Pile; CP: Compost Pile. Liquid samples and solid samples are separated by a red vertical line. 
Figure 3

PCA analysis 

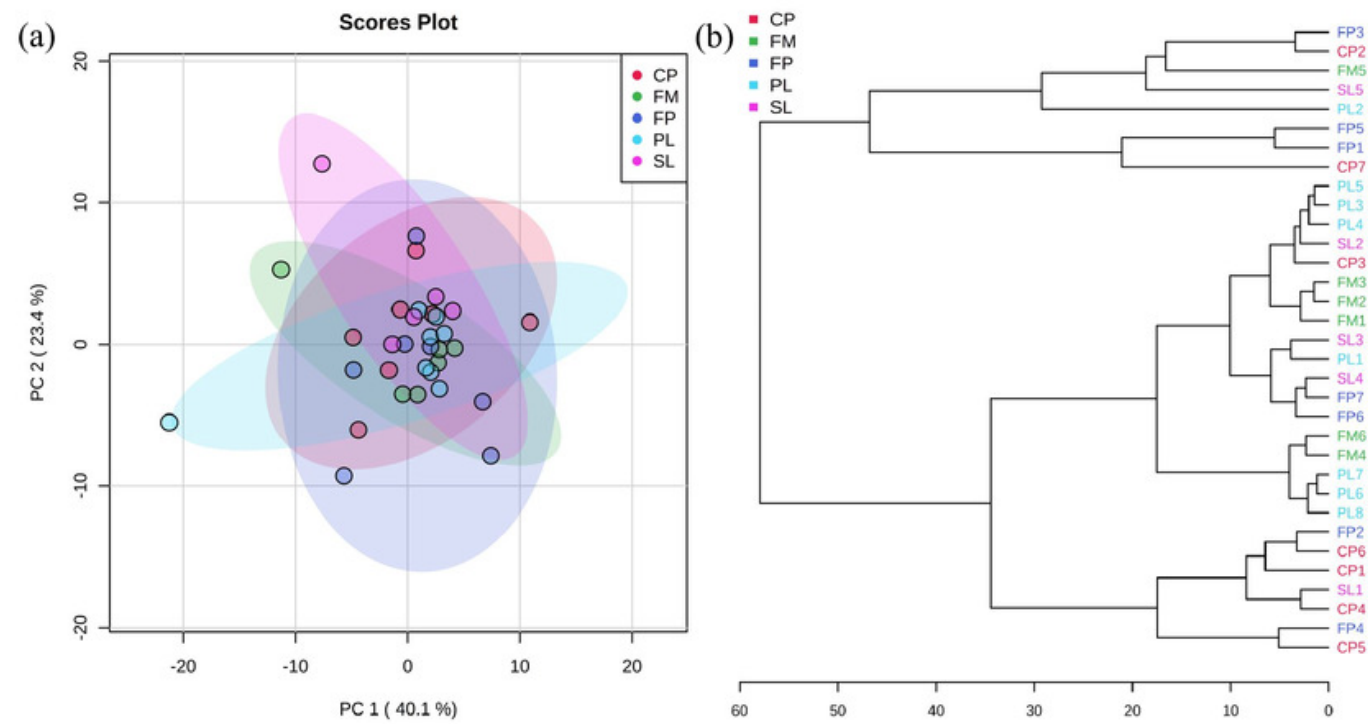

Figure 3 (a) Principal Component Analysis (PCA) Plot (Colors representing 95\% confidence regions). (b) Hierarchical Clustering Plot (distance measure using Euclidean, and clustering algorithm using Ward). 
Figure 4

Network analysis 


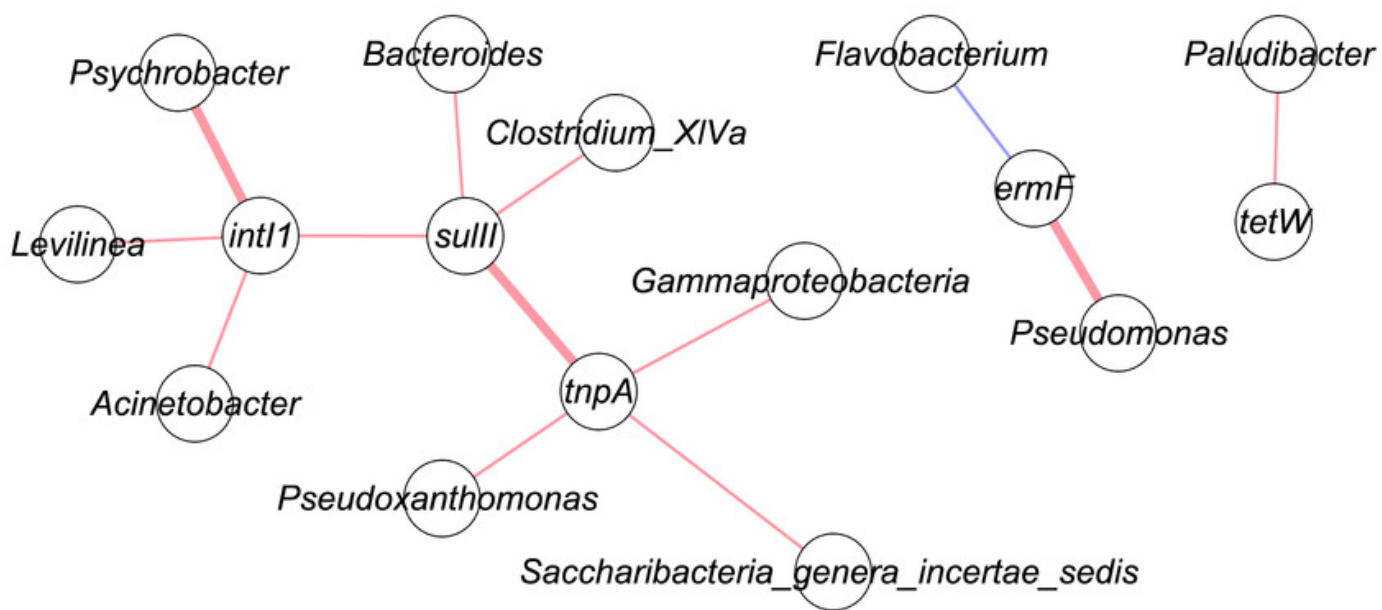

Figure 4 Network Analysis of targeted genes with bacterial communities. Red line: positive correlation; blue line: negative correlation; bold line: $p$-value $<0.05$.

1 